University of Wollongong

Research Online

Faculty of Informatics - Papers (Archive)

Faculty of Engineering and Information

Sciences

19-7-2005

\title{
Humancentric applications of RFID implants: the usability contexts of control, convenience and care
}

Amelia Masters

University of Wollongong, am16@uow.edu.au

Katina Michael

University of Wollongong, katina@uow.edu.au

Follow this and additional works at: https://ro.uow.edu.au/infopapers

Part of the Physical Sciences and Mathematics Commons

\section{Recommended Citation}

Masters, Amelia and Michael, Katina: Humancentric applications of RFID implants: the usability contexts of control, convenience and care 2005.

https://ro.uow.edu.au/infopapers/250

Research Online is the open access institutional repository for the University of Wollongong. For further information contact the UOW Library: research-pubs@uow.edu.au 


\title{
Humancentric applications of RFID implants: the usability contexts of control, convenience and care
}

\author{
Abstract \\ Recent developments in the area of RFID have seen the technology expand from its role in industrial and \\ animal tagging applications, to being implantable in humans. With a gap in literature identified between \\ current technological development and future humancentric possibility, little has been previously known \\ about the nature of contemporary humancentric applications. This paper utilizes usability context \\ analyses, to provide a cohesive study on the current development state of humancentric applications, \\ detached from the emotion and prediction which plagues this particular technology.

\section{Disciplines} \\ Physical Sciences and Mathematics

\section{Publication Details} \\ This paper originally appeared as: Masters, A \& Michael, K, Humancentric applications of RFID implants: \\ the usability contexts of control, convenience and care, WMCS '05. The Second IEEE International \\ Workshop on Mobile Commerce and Services, 19 July 2005, 32-41. Copyright IEEE 2005.
}




\title{
Humancentric Applications of RFID Implants: The Usability Contexts of Control, Convenience and Care
}

\author{
Amelia Masters, Katina Michael \\ University of Wollongong, School of Information Technology \& Computer Science \\ \{am16,katina\}@uow.edu.au
}

\begin{abstract}
Recent developments in the area of RFID have seen the technology expand from its role in industrial and animal tagging applications, to being implantable in humans. With a gap in literature identified between current technological development and future humancentric possibility, little has been previously known about the nature of contemporary humancentric applications. This paper utilizes usability context analyses, to provide a cohesive study on the current development state of humancentric applications, detached from the emotion and prediction which plagues this particular technology.
\end{abstract}

\section{Introduction}

Over the past three decades, Radio Frequency IDentification (RFID) systems have evolved to become cornerstones of many complex applications. From first beginnings, RFID has been promoted as an innovation in convenience and monitoring efficiencies. Indeed, with RFID supporters predicting the growth of key medical services and security systems, one manufacturer promoted the devices as "life-enhancing" [1]. Though the lifestyle benefits have long been known, only recently have humans become both integral and interactive components in RFID systems. Where we once carried smart cards or embedded devices interwoven in clothing, RFID technology is now at a point where humans can safely be implanted with small transponders.

This paper aims to explore the current state of development for humancentric applications of RFID. The current state is defined by the intersection of existing development for the subjects and objects of RFID- namely humans and implants. The need for such a study has been identified by a gap in knowledge between present applications and future possibility. Currently there is little public data relating to the existing development state. Moreover, even those employed with contemporary RFID development have a future focus [2]. On the other hand, detractors of the technology are quick to imply repression and Armageddon [3]. This study aims to overcome forecast and provide a cohesive examination of existing humancentric RFID applications. Analysis of future possibility is outside the scope of this study. Instead, discussion will be provided on present applications, their feasibility, use and benefit.

\section{Literature review}

The literature review is organized into three main areas- control, convenience, and care. In each of these contexts, literature will be reviewed chronologically.

\subsection{The context of control}

A control-related humancentric application of RFID is any human use of an implanted RFID transponder that allows an implantee to have power over an aspect of their lives, or, that allows a third party to have power over an implantee. Substantial literature on humancentric control applications begins in 1997 with United States patent 5629678 for a 'Personal Tracking and Recovery System'. Though the literature scientifically describes the theoretical tracking system for recovery of RFID-implanted humans, no further evidence is available to ascertain whether it has since been developed. Questions as to feasibility of use are not necessarily answered by succeeding literature. Reports of the implantation of British soldiers [4] for example lack the evidentiary support needed to assuage doubts. Further, many articles highlight the technological obstacles, what Eng calls "chipping blocks", besieging humancentric RFID systems. These include GPS hardware miniaturization and creating active RFID tags capable of being safely recharged 
from within the body. Further adding to reservation, much literature is speculative in nature. Eng [5], for example, predicts that tags will be melded into children to advise parents of their location, while Wakefield [6] predicts a future where microchipping for national security is common.

Despite concerns and conjecture, actual implementations of humancentric control applications of RFID have been identified. Both Murray [7] and Eng documented the implantation of Richard Seelig who had tags placed in his hip and arm as a security response to the September 11 tragedy of 2001. Similarly, Canadian artist Nancy Nisbet has implanted RFID microchips into her hands in order to question and apply control in personal environments [8].

\subsection{The context of convenience}

A convenience-related humancentric application of RFID is any human use of an implanted RFID transponder that increases the ease with which tasks are performed. The first major documented experiment into the use of human-implantable RFID was within this context. Pulse [9], Sanchez-Klein [10] and Witt [2] all journalize on the self-implantation of Kevin Warwick, Director of Cybernetics at the University of Reading. They define results of Warwick's research by his having doors open, lights switch on and computers respond to the presence of the microchip. Warwick himself gives a review of the research in his article 'Cyborg 1.0', however this report is informal and contains emotive descriptions of "fantastic" experiences [11].

Woolnaugh, [12] Holden, [13] and Vogel [14] all published accounts of the lead-up to Warwick's second 'Cyborg 2.0' experiment and although Woolnaugh's work involves the documentation of an interview, all three are narrative descriptions of proposed events rather than a critical analysis within definitive research frameworks. Though the commotion surrounding Warwick later died down, speculation did not with Eng proposing a future where credit card features will be available in implanted RFID devices. The result would see commercial transactions made more convenient.

\subsection{The context of care}

A care-related humancentric application of RFID is any human use of an implanted RFID transponder where function is associated with medicine, health or wellbeing. In initial literature, after the Cyborg 1.0 trial, Kevin Warwick envisioned that with RFID implants paraplegics would walk [2]. Building incrementally on this notion is the work of Kobetic, Triolo and Uhlir who documented the study of a paraplegic male who had muscular stimuli delivered via an implanted RFID controlled electrical simulation system [15]. Though not allowing the mobility which Warwick dreamt of, results did include increased energy and fitness for the patient.

Outside the research sphere, much literature centers on eight volunteers who were implanted with commercial VeriChip RFID devices in 2002. Murray [16], Black [17], Grossman [18], Streitfeld [19] and Gengler [20] all document medical reasons behind the implantation of four subjects. Supplemented by press releases though, all reports of the VeriChip trial were journalistic rather than research-based reporting. In contrast, non-trivial research is found in Michael's thesis [21] which uses a case study methodology and a Systems of Innovation framework to discuss the adaptation of auto-ID for medical implants.

\subsection{Critical response to literature}

Of the landmark studies, the majority are concerned with non-humancentric applications. Gerdeman [22], Finkinzeller [23] and Geers [24] all use case studies to investigate non-humancentric RFID and hence our methodological precedent is set. Of the remaining literature, the bulk is newstype in nature and the absence of research frameworks is evident. There are few exceptions to this, but they include Woolnaugh [12] who has used interviews, and Murray [7] and Eng [5] who provide small case studies. The real value in these news articles thus lies in the documentation of events. In further criticism the news articles do not demonstrate technological trajectories. Instead, many describe current events and then speculate on potential future developments rather than possible current applications. What is more, these future developments are often utopian implementations and are not likely to be achieved by incremental development in the short to medium-term.

\section{Methodology}

The primary question, "what is the current state of application development in the field of humancentric RFID devices?' is justifiably exploratory. It entails investigation into contemporary technology usage and seeks to clarify boundaries within the research area. As such, this is a qualitative study that uses some elements of descriptive research to enhance the central usability 
context analyses. These analyses are similar to case studies as they investigate "a contemporary phenomenon within its real life context when the boundaries between phenomenon and context are not clearly evident" [25]. They also similarly use multiple sources of evidence, however are differentiated on the basis of the unit of analysis [26]. In a usability context analysis methodology, units are not individuals, groups or organizations but are applications or application areas for a product, where 'product' is defined as "any interactive system or device designed to support the performance of users' tasks" [27]. The results of multiple analyses are more convincing than a singular study, and the broad themes identified cover the major fields of current humancentric RFID development. This ensures a thorough investigation of usage and context.

\section{Control}

The usability context analysis for control is divided into three main sub-contexts- security, management, and social controls (table 1).

\section{Table 1: Control usability sub-contexts}

\begin{tabular}{|c|c|c|c|}
\hline & Intended Users & Specific Uses & Constraints \\
\hline & $\begin{array}{l}\text { Mass market, } \\
\text { persons likely } \\
\text { to be involved } \\
\text { in high-risk } \\
\text { situations, the } \\
\text { elderly, } \\
\text { children }\end{array}$ & $\begin{array}{l}\text { Personal } \\
\text { identification, } \\
\text { location } \\
\text { based services }\end{array}$ & $\begin{array}{l}\text { Lack of } \\
\text { widespread } \\
\text { infrastructure, } \\
\text { need for reader } \\
\text { proximity to } \\
\text { RFID tags, data } \\
\text { correlation, } \\
\text { external GPS } \\
\text { integration }\end{array}$ \\
\hline & $\begin{array}{l}\text { Employees, } \\
\text { visitors to } \\
\text { restricted } \\
\text { locations }\end{array}$ & $\begin{array}{l}\text { Access } \\
\text { control, } \\
\text { monitoring }\end{array}$ & $\begin{array}{l}\text { Employee } \\
\text { consent, need } \\
\text { for reader } \\
\text { proximity to } \\
\text { tags, external } \\
\text { GPS integration }\end{array}$ \\
\hline & $\begin{array}{l}\text { Military } \\
\text { personnel, } \\
\text { police officers, } \\
\text { inmates, } \\
\text { parolees }\end{array}$ & $\begin{array}{l}\text { Monitoring, } \\
\text { crime } \\
\text { prevention }\end{array}$ & $\begin{array}{l}\text { Possible } \\
\text { involuntary use } \\
\text { of application, } \\
\text { external GPS } \\
\text { integration }\end{array}$ \\
\hline
\end{tabular}

\subsection{Security controls}

The most basic security application involves controlling personal identification through identifying data stored on a transponder. In theory, the limit to the amount of information stored is subject only to the capacity of the embedded device or associated database. Being secured within the body, the loss of the identifier is near impossible even though, as has occurred in herd animals, there are some concerns over possible dislodgement. Accordingly, the main usability drawback lies with reading the information. Implanted identification is useless if it is inaccessible.

The most commercial security application involves GPS tracking to pinpoint the location of an implantee [28]. Control here exists in both the ability to find and to be found. Suitable GPS components are currently manufactured and sold as stand-alone, wearable products by companies including Wherify Wireless [29]. Variants are available which send alerts to a nominated care-giver if the user wanders outside predefined boundaries or falls and remains immobile for an extended time. When combined with implanted RFID a superior level of identification is added to the application. This is especially valuable in allowing positive identification where the implantee is impaired or uncommunicative.

\subsection{Management controls}

Many smart card access systems use RFID technology to associate a cardholder with access permissions to particular locations. Replacing cards with RFID implants alters the form of the 'key' but does not require great change to verification systems. This is because information stored on a RFID microchip in a smart card can be stored on an implanted transponder. Readers can similarly be triggered when the transponder is nearby. This application would have greatest value in 'mission critical' workplaces or for persons whose role hinges upon access to a particular location. The implanted access pass has the added benefit of being permanently attached to its owner.

Access provision translates easily into employee monitoring applications. In making the implanted RFID transponder the access pass to certain locations or resources, times of access can be recorded to ensure that the right people are in the right place at the right time. Control in this instance then moves away from ideals of permission and embraces the notion of supervision. 


\subsection{Social controls}

In the military, transponders may serve as an alternative to dog tags. Using RFID, in addition to the standard name, rank and serial number, information ranging from allergies and dietary needs to shoe size can be stored. This purports to ease local administrative burdens and can eliminate the need to carry identifying documents in the field.

Just as humancentric applications of RFID exist for those who enforce law, so too do applications exist for people who have broken it. In 2002, 27 American states were using some form of satellite surveillance to monitor parolees [12]. Similar schemes have been used in Sweden since 1994 [30]. In most cases, parolees wear wireless wrist or ankle bracelets and carry small boxes containing the vital tracking technology. Economic benefits exist as it is cheaper for offenders to be monitored or to serve their sentences from home. Social benefits are also present as there is a level of certainty involved in identifying and monitoring socalled 'threats' to society.

With regard to mass market applications, one proposed use involves taking existing Infant Protection systems at birthing centers and internalizing the RFID devices worn by newborns. This would aid in identifying those who cannot identify themselves. Similarly, when connected to access sensors and alarms, the technology can alert staff to the "unauthorized removal of children" [31]. This example leads to more sinister scenarios. In South America for example, VeriChip is "commercialized as a way to identify kidnapping victims who are drugged, unconscious or dead. In that market, the chip is being bundled with the... GPS device, Digital Angel, so police are able to track the abduction victim's location as well" [32].

\section{Convenience}

The usability context analysis for convenience is divided into three main sub-contexts- assistance, financial services and interactivity (table 2).

\subsection{Assistance}

Automation is the repetition of a process through technological means. Implied in the process is a relationship, the most common of which involves linking an implantee with appropriate data. Such information in convenience contexts however can be extended to encompass physical objects with which the implantee has an association of ownership or bailment. VeriChip for example, a manufacturer of implantable RFID chips, have developed VeriTag for use in travel. This device allows "personnel to link a VeriChip subscriber to his or her luggage... flight manifest logs and airline or law enforcement software databases" [33]. Convenience is provided for the implantee who receives greater assurance that their luggage will arrive at the correct destination, and also for the transport operator who is able to streamline processes using better identification and sorting measures.

Advancing the notion of timing, processes involving movement lead to applications that can locate an implantee or find an entity relative to them. This includes "find a friend", "where am I", "where is the nearest" and "guide me to" solutions. Integrating RFID and GPS technologies with a geographic information system (GIS) portal such as the Internet-based mapquest.com would allow users to find destinations based on their current GPS location. The nature of the application also lends itself toward roadside assistance or emergency services, where the atypical circumstances surrounding the service may mean that other forms of subscriber identification are unavailable.

\section{Table 2: Convenience usability sub-contexts}

\begin{tabular}{|c|c|c|}
\hline Intended Users & Specific Uses & Constraints \\
\hline $\begin{array}{l}\text { Mass market, } \\
\text { travelers, } \\
\text { athletes, car } \\
\text { owners }\end{array}$ & \begin{tabular}{|l|} 
Identification \\
of objects, \\
location \\
based \\
services, \\
roadside \\
assistance, \\
emergency \\
services
\end{tabular} & $\begin{array}{l}\text { RF interference, } \\
\text { need for an } \\
\text { appropriate } \\
\text { placement of the } \\
\text { transponder to } \\
\text { facilitate } \\
\text { accurate } \\
\text { reading, external } \\
\text { GPS integration, } \\
\text { GPS will not } \\
\text { work indoors }\end{array}$ \\
\hline Mass market & \begin{tabular}{|l|} 
Credit or \\
debit \\
facilities, \\
identification \\
of transaction \\
owner. \\
\end{tabular} & $\begin{array}{l}\text { Lack of } \\
\text { widespread } \\
\text { infrastructure, } \\
\text { cannot eliminate } \\
\text { all human } \\
\text { interaction }\end{array}$ \\
\hline $\begin{array}{l}\text { Mass market, } \\
\text { home owners, } \\
\text { office dwellers, } \\
\text { car owners }\end{array}$ & $\begin{array}{l}\text { Interactive } \\
\text { buildings, } \\
\text { keyless entry } \\
\text { systems, } \\
\text { remote } \\
\text { control of } \\
\text { devices }\end{array}$ & $\begin{array}{l}\text { Need for } \\
\text { advanced } \\
\text { infrastructure, } \\
\text { close proximity } \\
\text { between readers } \\
\text { and RFID tags }\end{array}$ \\
\hline
\end{tabular}




\subsection{Financial services}

Over the last few decades, world economies have come to see the rise of the cashless society. In recent years, alongside traditional contact cards, we have seen the emergence of alternate payment processes- RFID being one of these. In 2001, Nokia tested the use of RFID in its 5100-series phone covers, allowing the mobile device to be used as a bank facility. RFID readers were placed at McDonalds drive-through restaurants in New York and the consumer was able to pay their bill by holding their mobile phone to a reader. The reader contacted a wireless banking network and payment was deducted from a credit or debit account. Of the trial, Wired News noted the convenience stating, "there is no dialing, no ATM, no fumbling for a wallet or dropped coins" [34]. These benefits would similarly exist with implanted RFID and the feasibility has been noted with Ramo commenting "in the not too distant future" money could be stored anywhere, as well as "on a chip implant under skin" [35].

It is also feasible that humancentric RFID eliminates the need to stand in line at a bank. Purely as a means of identification, the unique serial or database access key stored on the RFID transponder can be used to prove identity when opening an account. The need to present paper identification is removed and, conveniently, the same identification used to open the account is instantly available when making further transactions. This has similar benefits for Automatic Teller Machines as when intermediary transaction devices are fitted with RFID readers, RFID transponders have the ability to replace debit and credit cards.

\subsection{Interactivity}

On August 24, 1998 Professor Kevin Warwick became the first recorded human to be implanted with an RFID device. Using the transponder, Warwick was able to interact with the 'intelligent' building that he worked in. Over the nine days he spent implanted, doors previously requiring smart card access, automatically opened. Lights activated when the Professor entered a room and within his office, upon sensing Warwick's presence, his computer greeted him. The 'Project Cyborg 1.0' experiment thus showed enormous promise for humancentric convenience applications of RFID. The concept of such stand-alone applications expands easily into the development of Personal Area Networks (PAN), such as an interactive home or office. With systems available to manage door, light and personal computer preferences based on transponder identification, further climate and environmental changes are similarly exploitable (especially considering non-humancentric versions of these applications activated by wearable RFID already exist) [36].

Given the success of interacting with inanimate locations and objects, the next step is to consider whether person-to-person communication can be achieved using humancentric RFID. Such communication would conveniently eliminate the need for intermediary devices like telephones or post. Answering this question was an aim of 'Project Cyborg 2.0' with Warwick writing, "We'd like to send movement and emotion signals from one person to the other, possibly via the Internet" [37]. Warwick's wife Irena was the second trial subject, being similarly fitted with an implant in her median nerve. Communicating via computer-mediated signals was met with limited success however. When Irena clenched her fist for example, Professor Warwick received a shot of current through his left index finger [38]. Movement sensations were therefore effectively, though primitively, transmitted.

\section{Care}

The usability context analysis for care is divided into three main sub-contexts- medical, biomedical and therapeutic (table 3).

\subsection{Medical}

As implanted transponders contain identifying information, the storage of medical records is an obvious humancentric care application of RFID. Similar to other identification purposes, a primary benefit involves the RFID transponder imparting critical information when the human host is otherwise incapable of communicating. In this way, the application is "not much different in principle from devices... such as medic-alert bracelets" [20]. American corporation VeriChip markets their implantable RFID device for this purpose. Approved for distribution throughout the United States in April of 2002, it has been subject to regulation (as a medical device) by the Food and Drug Administration (FDA) since October of the same year.

Care-related humancentric RFID devices provide unparalleled portability for medical records. Full benefit cannot be gained without proper infrastructure 
however. Though having medical data instantly accessible through implanted RFID lends itself to saving lives in an emergency, this cannot be achieved if reader equipment is unavailable. The problem is amplified in the early days of application rollout, as the cost of readers may not be justified until the technology is considered mainstream. Also, as most readers only work with their respective proprietary transponders, questions regarding market monopolies and support for brand names arise.

Table 3: Care usability sub-contexts

\begin{tabular}{|c|c|c|c|}
\hline & Intended Users & Specific Uses & Constraints \\
\hline & $\begin{array}{l}\text { Mass market, } \\
\text { persons with } \\
\text { allergies, } \\
\text { persons with } \\
\text { chronic medical } \\
\text { conditions }\end{array}$ & $\begin{array}{l}\text { Storage and } \\
\text { portability of } \\
\text { medical } \\
\text { records, } \\
\text { patient } \\
\text { identification } \\
\end{array}$ & $\begin{array}{l}\text { Lack of } \\
\text { widespread } \\
\text { infrastructure, } \\
\text { external GPS } \\
\text { integration }\end{array}$ \\
\hline & $\begin{array}{l}\text { Sufferers of } \\
\text { chronic disease, } \\
\text { trauma victims, } \\
\text { those taking } \\
\text { regular } \\
\text { medication, in- } \\
\text { patients }\end{array}$ & $\begin{array}{l}\text { Monitoring of } \\
\text { biological } \\
\text { parameters } \\
\text { for medical } \\
\text { and health- } \\
\text { related care } \\
\text { purposes }\end{array}$ & $\begin{array}{l}\text { Implant attacked } \\
\text { or rejected by } \\
\text { the human host, } \\
\text { implant } \\
\text { dislodgement, } \\
\text { lack of } \\
\text { widespread } \\
\text { infrastructure, } \\
\text { limited } \\
\text { development and } \\
\text { human testing }\end{array}$ \\
\hline & $\begin{array}{l}\text { Those with } \\
\text { previously } \\
\text { implanted } \\
\text { therapeutic } \\
\text { devices, those } \\
\text { in need of } \\
\text { remedial care, } \\
\text { disabled } \\
\text { persons }\end{array}$ & $\begin{array}{l}\text { Monitoring of } \\
\text { implanted } \\
\text { devices, } \\
\text { physiotherapy }\end{array}$ & $\begin{array}{l}\text { System } \\
\text { complexity, } \\
\text { material } \\
\text { constraints, } \\
\text { computational } \\
\text { ability, power, } \\
\text { robustness and } \\
\text { fault tolerance, } \\
\text { scalability and } \\
\text { continuous } \\
\text { operation }\end{array}$ \\
\hline
\end{tabular}

\subsection{Biomedical}

A biosensor is a device which "detects, records, and transmits information regarding a physiological change or the presence of various chemical or biological materials in the environment" [39]. It combines biological and electronic components to produce quantitative measurements of biological parameters, or qualitative alerts for biological change. Thermal, electrochemical, mass and optical measures are most commonly monitored. When integrated with humancentric RFID, biosensors can transmit source information as well as biological data. The time savings in simultaneously gathering two distinct data sets are thus an obvious benefit. Further, combined reading of the biological source and measurement is less likely to encounter the human error linked with manually correlating data to data sources [40].

Implantable transponders allowing for the measurement of body temperature have been used to monitor livestock for over a decade [24]. As such, the data procurement benefits are well known. It does however give a revolutionary new facet to human care by allowing internal temperature readings to be gained, post-implantation, through non-invasive means. The applications for this are wide and include: chemotherapy treatment management; chronic infection or critical care monitoring; organ transplantation treatment management; infertility management; post-operative or medication monitoring; and response to treatment evaluation.

An implantable RFID device for use by diabetes sufferers has been prototyped by biotechnology firm M-Biotech. The small glucose bio-transponder, consisting of a miniature pressure sensor and a glucose-sensitive hydrogel swells "reversibly and to varying degrees" when changes occur in the glucose concentrations of surrounding fluids [41]. Implanted in the abdominal region, a wireless alarm unit carried by the patient continually reads the data, monitoring critical glucose levels.

\subsection{Therapeutic}

Implanted therapeutic devices are not new. Alongside the use of artificial joints for example, radical devices such as pacemakers have become commonplace. The use of RFID with these devices however, has re-introduced a novelty to the remedial solution. This is because, while the therapeutic devices remain static in the body, the integration of RFID allows for interactive status readings and monitoring, through identification of the device.

There are very few proven applications of humancentric RFID in the treatment usability subcontext at current if one puts cochlear implants [42] and smart pills aside [43]. Further, of those applications at the proof of concept stage, benefits to the user are generally gained via an improvement to the quality of living, and not a cure for disease or disability. With applications to restore sight to the blind and re-establish normal bladder function for 
patients with spinal injuries already in prototyped form, some propose that real innovative benefit is only a matter of time. Arguably the technology for the applications already exists [44]. All that needs to be demonstrated is a correct implementation. Thus, feasibility is perhaps a matter of technological achievement and not technological advancement.

\section{Discussion}

The choice of control, convenience and care contexts for analysis stemmed from the emergence of separate themes in the literature review; however the context analyses themselves showed much congruence between application areas. In all contexts, identification and monitoring are core functions. For control, this functionality exists in security and in management of access to locations and resources. For convenience, identification necessarily provides assistance and monitoring supports interactivity with areas and objects. Care, as the third context, requires identification for medical purposes and highlights biological monitoring as basic functionality.

With standard identification and monitoring systems as a basis, it is logical that so many humancentric applications of RFID have a mass target market. Medical identification for example is not solely for the infirm because, as humans, we are all susceptible to illness. Similarly, security and convenience are generic wants. Combined with similarities between contextual innovations, massmarket appeal can lead to convergence of applications. One potential combination is in the area of transportation and driver welfare. Here the transponder of an implanted driver could be used for keyless passive entry (convenience), monitoring of health (care), location based services (convenience), roadside assistance (convenience) and, in terms of fleet management or commercial transportation, driver monitoring (control).

Despite parallels and a potential for convergence, development contexts for humancentric RFID are not equal. Instead, control is dominant. Though care can lead to control and medical uses are also convenient, it is control which filters through other contexts as a central tenet. In convenience applications, control is in the power of automation and mass management, in the authority over environments and devices. For care applications, medical identification is a derivative of identification for security purposes and the use of biosensors or therapeutic devices extends control over well-being. Accordingly, control is the overriding theme encompassing all contexts of humancentric RFID in the current state of development [45].

Alongside the contextual theme encapsulating the usability contexts are the corresponding benefits and costs of each area (table 4). When taking a narrow view and analyzing a sub-context, it is clear that many benefits of humancentric RFID are application specific. Therapeutic implants for example, have the benefit of the remedy itself. Also from this viewpoint particular implementations of applications are largely given to social disadvantages including the onset of religious objections and privacy fears.

\section{Table 4: Comparative benefits and costs}

\begin{tabular}{|c|c|}
\hline $\begin{array}{c}\text { Humancentric } \\
\text { Applications }\end{array}$ & $\begin{array}{l}\text { Humancentric } \\
\text { RFID Devices }\end{array}$ \\
\hline $\begin{array}{l}\text { Improved control, } \\
\text { enhanced security, } \\
\text { increased convenience, } \\
\text { improved care, accurate } \\
\text { identification, theft-proof, } \\
\text { counterfeit-proof, access } \\
\text { control, resource } \\
\text { monitoring, location } \\
\text { tracking and emergency } \\
\text { alert (with GPS), } \\
\text { interactive locations and } \\
\text { devices, biosensing, } \\
\text { streamlined processes, data } \\
\text { portability, time savings, } \\
\text { economic benefits, implant } \\
\text { is hidden, tag cannot be } \\
\text { forgotten or 'lost' }\end{array}$ & $\begin{array}{l}\text { Secured within the } \\
\text { body, reduced theft } \\
\text { and loss of } \\
\text { components, serial } \\
\text { numbers and } \\
\text { passwords on the } \\
\text { transponder are } \\
\text { imperceptible to the } \\
\text { naked eye }\end{array}$ \\
\hline $\begin{array}{l}\text { Lack of widespread reading } \\
\text { infrastructure, need for } \\
\text { data correlation, need for a } \\
\text { standardized placement of } \\
\text { the transponder to facilitate } \\
\text { accurate reading, possible } \\
\text { involuntary use of } \\
\text { application, crude success } \\
\text { in human-to-human } \\
\text { communications }\end{array}$ & $\begin{array}{l}\text { Material constraints, } \\
\text { computational ability, } \\
\text { low power, wireless } \\
\text { interference, system } \\
\text { complexity, fault } \\
\text { tolerance, need for } \\
\text { continuous operation, } \\
\text { robustness, implant } \\
\text { attacked or rejected } \\
\text { by the human host, } \\
\text { dislodgement, close } \\
\text { proximity between } \\
\text { reader \& tag, external } \\
\text { GPS integration }\end{array}$ \\
\hline
\end{tabular}

\subsection{Application quality and service support}

For humancentric RFID, application quality depends on commercial readiness and the usability 
context analyses suggest that the technology, and not the applications, present the largest hurdle. In his Cyborg 1.0 experiments for example, Professor Kevin Warwick kept his transponder implanted for only nine days, as a direct blow would have shattered the glass casing, irreparably damaging nerves and tissue. Similarly, research into location based services faces technological hurdles as combining GPS with humancentric RFID involves challenges of radiation shielding, miniaturization and power supply.

Once technological difficulties are overcome and applications move from proof of concept into commercialization, market concerns are more relevant. Quality of data for instance, is a key issue. In VeriChip applications, users control personal information that is accessible, though stored in the Global VeriChip Subscriber Registry, through their implanted transponder. The system does not appear to account for data correlation however, and there is a risk of human error in information provision and in data entry. Thus, who pays for errors? Who maintains liability? Such questions indicate the need for industry standards, allowing a quality framework for humancentric RFID applications to be created and managed.

Industry standards are also relevant to support services. In humancentric applications of RFID they are especially needed as much usability, adjunct to the implanted transponder, centers upon peripherals and their interoperability. Most proprietary RFID readers for instance, can only read data from similarly proprietary transponders. In medical applications though, where failure to harness available technology can have dramatic results, an implantee with a noncompatible and therefore unreadable transponder, is no better off for using the application. Accordingly, for humancentric RFID to realize its promotion as 'lifeenhancing', standards for compatibility between differently branded devices must be developed.

Lastly, the implantation site should be standardized as even if an implanted transponder is known to exist, difficulties may arise in discerning its location. Indeed, on the list of notable implantees, the Jacobs family has transponders in their right arms, while Kevin Warwick opted for his left. Richard Seelig has transponders in his arm and hip, while British soldiers in unconfirmed trials allegedly carried transponders in their necks. Without a common site for implantation, and where scanning an implanted transponder requires a proximity of less than a few centimeters, finding an implanted RFID device can be tedious. This is disadvantageous for medical, location-based or other critical implementations where time is a decisive factor in the success of the application. It is also a disadvantage in more general terms as the lack of standards suggests that though technological capability is available, there is no social framework ready to accept it.

\subsection{Commercial viability for consumers}

A humancentric application of RFID must satisfy a valid need to be considered marketable. This is especially crucial as the source of the application, the transponder, requires an invasive installation and, afterwards, cannot be easily removed. Add to this that humancentric RFID is a relatively new offering with few known long-term effects, and participation is likely to be a highly considered decision. Thus, despite many applications having a mass target market, the value of the application to the individual will determine boundaries and commercial viability.

Value is not necessarily cost-based. Indeed, with the VeriChip sold at around \$US200 plus a \$10 per month information storage fee, it is not being marketed as a toy for the elite. Instead, value and application scope are assessed in terms of life enhancement. Therapeutic devices for example, provide obvious remedial benefit; but the viability of a financial identification system may be limited by available infrastructure. Similarly, is implanting for precaution against kidnapping or terrorism really worthwhile if it simply serves as a means of identification after death?

Arguably, commercial viability is increased by the ability of one transponder to support multiple applications. Identification applications for example, are available in control, convenience and care usability contexts. Likewise, one humancentric RFID-GPS system can support many location-based services. The question arises however, as to what occurs when different manufacturers market largely different applications? Where no real interoperability exists for humancentric RFID devices, it is likely that users must be implanted with multiple transponders from multiple providers. Further given the power and processing constraint of multi-application transponders in the current state of development, the lack of transponder portability reflects negatively on commercial viability and suggests that each application change or upgrade may require further implantation and bodily invasion.

\subsection{Commercial viability for manufacturers}

Taking VeriChip as a case study, one is led to believe that there is a commercially viable market for humancentric applications of RFID. Indeed, where the 
branded transponder is being sold in North and South America, and has been showcased in Europe [46], a global want for the technology is suggested. It must be recognized however, that in the current state of development VeriChip and its parent, Applied Digital Solutions, have a monopoly over those humancentric RFID devices approved for use. As such, their statistics and market growth have not been affected by competition and there is no comparative data. The difference between a successful public relations campaign and reality is therefore hard to discern.

Interestingly, in non-humancentric commercial markets, mass rollouts of RFID have been scaled back. Problems have arisen specifically in animal applications. The original implementation of the 1996 standards, ISO 11784: 'Radio-frequency identification of animals- Code structure' and ISO 11785: 'Radiofrequency identification of animals- Technical concept' for example, were the subject of extensive complaint [47]. Not only did the standards not require unique identification codes, they violated the patent policy of the International Standards Organization. Also, owing to three conflicting patents affecting ISO 11785 , the standards infringed antitrust law in several countries. Even after the ISO standards were returned to the SC19 Working Group 3 for review, a general lack of acceptance equated to limited success. Moreover, in recent times, moves have been made to ban the use of implantable transponders in herd animals. In a high percentage of cases the transponder moved in the fat layer, raising concerns that it might be later consumed by humans. Further, the meat quality was degraded as animals sensing the existence of an implanted foreign object produced antibodies to attack it [21].

Where humancentric applications of RFID have been influenced by and built upon non-humancentric applications, the cessation of non-humancentric trials and the reduction in herd animal implantation is not a positive sign for the humancentric RFID industry. It instead shows the niche functionality of the technology and suggests that gaining long-term commercial viability will be fraught with problems.

\section{Conclusion}

In the current state of humancentric development, stand-alone applications exist for control, convenience and care purposes, but as control is the dominant context, its effects are seen in other application areas. Applications are also influenced by power and processing confines, and as such, many functions have simple bases in identification or monitoring. Application usage is made more complex however, as a need for peripherals (including readers, information storage systems and, in some cases, GPS) is coupled with a lack of industry standards for interoperability. Though the technology has been deemed feasible in both research and commercially approved contexts, the market for humancentric applications of RFID is still evolving. Initial adoption of the technology has met with some success but, as research continues into humancentric applications of RFID, the market is still too niche for truly low-cost, high-quality application services. Any real assessment of the industry is further prejudiced by the commercial monopoly of the VeriChip Corporation. Assessment of feasibility is also constrained by limited research into long-term effects and, where use in herd animals has seen the transponders dislodged or attacked by the immune system; this presents a negative view of humancentric RFID. Thus, even without taking social responses into account, the long-term commercial viability for humancentric applications of RFID is questionable. In the short to medium-term, adoption of humancentric RFID technology and use of related applications will be hindered by a lack of infrastructure and a lack of standards, not only as to interoperability, but also as to support for service and transponder placement.

\section{References}

[1] Anonymous, "Skin Deep: Human Microchip Gets Green Light For U.S. Distribution", Wireless News, April 5, 2002, Available ProQuest, March 182003.

[2] S. Witt, "Professor Warwick Chips In", Computerworld, 33(2), January 11, 1999, pp. 89-90.

[3] K. Michael \& M.G. Michael, "The Social, Cultural, Religious and Ethical Implications of Automatic Identification", Proceedings of the Seventh International Conference on Electronic Commerce Research, Texas US, 2004, pp. 432-450.

[4] D. Icke, "Has The Old ID Card Had Its Chips?" Soldier Magazine. April, 2001.

[5] P. Eng, "I Chip?” ABC News.com, March 1, 2002.

[6] J. Wakefield, "Chips To Fight Kidnapping", BBC News Online, March 24, 2002.

[7] C. Murray, "Injectable Chip Opens Door To Human Bar Code", EETimes, January 7, 2002 [http://www.eetimes.com/ story/OEG20020104S0044 Last Accessed: May 8, 2003].

[8] J. Scheeres, "New Body Art: Chip Implants", Wired News, March 11, 2002, [http://www.wired.com/news/ culture/0,1284,50769,00.html Last Accessed April 3, 2003].

[9] Anonymous, "GP Creates Cyberman In Surgery", Pulse [Online] London, September 5, 1998, Available ProQuest May 1, 2003. 
[10] J. Sanchez-Klein, "And Now For Something Completely Different", PC World Online San Francisco. August 27, 1998, Available ProQuest, May 1, 2003.

[11] K. Warwick, "Cyborg 1.0", Wired Magazine, 8.02 February 2000, [http://www.wired.com/wired/archive/8.02/ warwick.html Last Accessed: April 9, 2003].

[12] R. Woolnaugh, "A Man With A Chip In His Shoulder", Computer Weekly, June 29, 2000, Available Expanded Academic Index, May 1, 2003.

[13] C. Holden, "Hello Mr Chip", Science Washington, March 23, 2001, Available ProQuest, May 1, 2003.

[14] G. Vogel, "Part Man, Part Computer" Science Washington, 295(5557) February 8, 2002, p. 1020, Available Expanded Academic Index, May 1, 2003.

[15] R. Kobetic et al, "Implanted Functional Electrical Simulation System for Mobility in Paraplegia", IEEE Transactions on Rehabilitation Engineering, December 1999, Available ProQuest April 29, 2003.

[16] C. Murray, "Prodigy Seeks Out High-tech Frontiers", Electronic Engineering Times, February 25, 2002, Available ProQuest, March 18, 2003.

[17] J. Black, "Roll Up Your Sleeve For A Chip Implant", BusinessWeek Online, Business Week Magazine, March 21, 2002, [http://www.businessweek.com/bwdaily/dnflash/mar20 02/nf20020321_1025.htm Last Accessed: April 8, 2003].

[18] L. Grossman, "Meet The Chipsons", Time, New York, 159(10), March 11, 2002, pp. 56-57.

[19] D. Streitfeld, "Chips To Be Implanted In Humans", Los Angeles Times, May 10, 2002, Available LexisNexis, April 7, 2003.

[20] B. Gengler, "Chip Implants Become Part of You", The Australian, September 10, 2002.

[21] K. Michael, "The Technological Trajectory of the Automatic Identification Industry", University of Wollongong, Australia, Unpublished Thesis, 2003.

[22] J. Gerdeman, Radio Frequency Identification Application 2000, Research Triangle Consultants Inc, North Carolina, 1995.

[23] K. Finkinzeller, RFID Handbook: Radio-Frequency Identification Fundamentals and Applications, John Wiley \& Sons Ltd, England, 2001.

[24] R. Geers et al, Electronic Identification, Monitoring and Tracking of Animals, CAB, United Kingdom, 1997.

[25] R. Yin, "The Case Study Method As A Tool For Doing Evaluation", Current Sociology, 41(1), 1998, p. 123.

[26] J.R. Tuttle, "Traditional and Emerging Technologies and Applications in the Radio Frequency Identification (RFID) Industry", Radio Frequency Integrated Circuits (RFIC) Symposium IEEE, June 8-11, 1997, pp. 5-8.

[27] C. Thomas \& N. Bevan, Usability Context Analysis: A Practical Guide, Serco Usability Services National Physical Laboratory, Teddington, Middlesex, 1996.

[28] K. Michael, "Location-Based Services: A Vehicle for IT\&T Convergence", In K. Cheng et al., Advances in Eengineering \& Digital Enterprise Technology, UK Professional Engineering Publishing, 2004, pp. 467-477.

[29] Wherify Wireless: Corporate Home, Wherify Wireless Location Services, Redwood Shores California [http://www. wherifywireless.com/corp_home.htm, Last Accessed: May 3, 2003].
[30] H. van Hofer, "Notes On Crime And Punishment In Sweden And Scandinavia", 115th International Training Course Visiting Experts Papers, 57, United Nations Asia, 2000, pp. 284-313, [http://www.unafei.or.jp/pdf/57-21.pdf Last Accessed: September 3, 2003].

[31] Vxceed, RFID Technology, Vxceed Technologies, 2003 [http://www.vxceed.com/developers/rfid.asp Last Accessed: September 20, 2003].

[32] J. Scheeres, "Politician Wants to Get Chipped", Wired News, February 15, 2002, [http://www.wired.com/news/print/ 0,1294,50435,00.html Last Accessed: May 3, 2003].

[33] Applied Digital Solutions, "Protected by VeriChip" Awareness Campaign Continues", Press Release, Applied Digital Solutions, Palm Beach, July 2, 2002.

[34] L. Nadile, "Call Waiting: A Cell Phone ATM", Wired News, San Francisco, 2003 [http://www.wired.com/news/ business/0,1367,41023,00.html Accessed: Sept 19, 2003].

[35] J.C. Ramo, "The Big Bank Theory and What It Says About the Future of Money", Time, April, 1998, pp. 46-55.

[36] Texas Instruments, "Loyally Yours", TIRIS News, Dallas, 17, 1997, [http://www.ti.com/tiris/docs/manuals/ RFIDNews/Tiris_NL17.pdf Last Accessed: May 1, 2003].

[37] K. Warwick, "Project Cyborg 2.0", Kevin Warwick. [http://www.rdg.ac.uk/KevinWarwick/html/project_cyborg_2 _0.html Last Accessed: January 4, 2003].

[38] W. Underhill, "Merging Man and Machine", Newsweek, 38, October 14, 2002, Expanded Academic Index, May 1, 2003.

[39] T. Seneadza, "Biosensors- A Nearly Invisible Sentinel", Technically Speaking, July 21, 2003, [http://tonytalkstech .com/archives/000231.php, Accessed: October 15, 2003].

[40] W. Wells, "The Chips Are Coming. Biotech Applied", [http://www.accessexcellence.com/AB/BA/biochip.html Last Accessed: November 22, 2001].

[41] M-Biotech, "Biosensor Technology", M-Biotech, Salt Lake City, 2003, [http://www.m-biotech.com/technology1. html Last Accessed: October 7, 2003].

[42] Cochlear, "Nucleus 24 Cochlear Implant", Cochlear, 1999, [http://www.Cochlear.com/euro/nucleussystems/ci24m .html Last Accessed June 3, 1999].

[43] Sun-Sentinel, "The Smart Pill”, Sun-Sentinel News: The Edge, [http://www.sun-sentinel.com/graphics/news/smartpill Last Accessed April 3, 2003].

[44] K. Mieszkowski, "Put That Silicon Where the Sun Don't Shine", Salon.com, [http://www.salon.com/tech /feature/2000/09/07/chips/ Vols. 1-3, Last Accessed November 11, 2001].

[45] K. Michael \& A. Masters, "Applications of Human Transponder Implants in Mobile Commerce", In N. Callaos et al, Eighth World Multiconference on Systemics, Cybernetics and Informatics, Orlando Florida, 2004, pp. 505-512.

[46] Applied Digital Solutions, "VeriChip" Subdermal Personal Verification Microchip", ADSX, 2003.

[47] RFID News, "International Standards Organization Returns RFID Standard For Animal Use To Working Group For Major Revisions", RFID News, 2002, [http://www.rfidnews.com/returns.html Accessed: October 2003]. 